\title{
Pengaruh PAD, DAU, dan DAK Terhadap Produk Domestik Bruto di Provinsi
}

\section{Lampung Periode 2016-2018}

\author{
Yohana Dwi Fitriani, Agnes Susana Merry P.* \\ STIE Gentiaras Bandar Lampung, Lampung \\ *email: agnessusana3@gmail.com
}

\begin{tabular}{|c|c|}
\hline$A R T I C L E \quad I N F O$ & $A B S T R A C T$ \\
\hline $\begin{array}{l}\text { Artikel History: } \\
\text { Received:July 16, } 2021 \\
\text { Revised: July 30, } 2021 \\
\text { Published:July 31, } 2021\end{array}$ & \multirow{2}{*}{$\begin{array}{l}\text { Lampung is one of the provinces in Indonesia that feels the impact of regional } \\
\text { autonomy, so a measuring tool is needed to determine the economic condition per } \\
\text { period through gross regional domestic product. The purpose of this study is to } \\
\text { determine the effect of Regional Original Income, General Allocation Funds, and } \\
\text { Special Allocation Funds on GRDP. This study uses a quantitative approach. The } \\
\text { type of data used is secondary data found on the official website of BPS Lampung. } \\
\text { The type of data used is time series data in the 2016-2018 period and cross section } \\
\text { data for } 15 \text { districts/cities in Lampung Province. The statistical analysis method } \\
\text { used is multiple linear regression analysis, using the SPSS } 20 \text { program. The results } \\
\text { of the analysis conclude that: Regional Original Income has a positive effect on } \\
\text { GRDP, General Allocation Funds have a positive effect on GRDP, and the Special } \\
\text { Allocation Fund K has no effect and is negative on GRDP. GRDP. Simultaneously, } \\
\text { the variables of Regional Original Revenue, General Allocation Fund, and Special } \\
\text { Allocation Fund have a significant effect on GRDP. }\end{array}$} \\
\hline $\begin{array}{l}\text { Keywords: } \\
\text { Regional Original Revenue, } \\
\text { General Allocation Fund, } \\
\text { Special Allocation Fund, GRDP }\end{array}$ & \\
\hline I N F O A R T I K E L & B S T R A K \\
\hline $\begin{array}{l}\text { Riwayat Artikel: } \\
\text { Diterima: } 16 \text { Juli } 2021 \\
\text { Direvisi: } 30 \text { Juli } 2021 \\
\text { Dipublikasikan: } 31 \text { Juli } 2021\end{array}$ & \multirow{2}{*}{$\begin{array}{l}\text { Lampung merupakan salah satu Propinsi di Indonesia yang merasakan dampak } \\
\text { otonomi daerah, sehingga dibutuhkan alat ukur untuk mengetahui kondisi ekonomi } \\
\text { per periodenya melalui produk domestik regional bruto. Tujuan penelitian ini untuk } \\
\text { mengetahui pengaruh Pendapatan Asli Daerah, Dana Alokasi Umum, dan Dana } \\
\text { Alokasi Khusus terhadap PDRB. Penelitian ini menggunakan pendekatan kuantitatif } \\
\text { Jenis data yang digunakan adalah data sekunder yang terdapat di website resmi BPS } \\
\text { Lampung. Jenis data yang digunakan adalah data time series dalam kurun waku } \\
2016-2018 \text { dan data cross section } 15 \text { Kabupaten/Kota di Provinsi Lampung. Metode } \\
\text { analisis statistik yang digunakan adalah analisis regresi linier berganda, } \\
\text { menggunakan bantuan program SPSS 20. Hasil analisis memberikan kesimpulan } \\
\text { bahwa: Pendapatan Asli Daerah berpengaruh positif terhadap PDRB, Dana Alokasi } \\
\text { Umum berpengaruh positif terhadap PDRB, dan Dana Alokasi Khusus K tidak } \\
\text { berpengaruh dan bersifat negatif terhadap PDRB. Secara simultan variabel } \\
\text { Pendapatan Asli Daerah, Dana Alokasi Umum, dan Dana Alokasi Khusus } \\
\text { berpengaruh signifikan terhadap PDRB. }\end{array}$} \\
\hline $\begin{array}{l}\text { Kata kunci: } \\
\text { Pendapatan Asli Daerah, Dana } \\
\text { Alokasi Umum, Dana Alokasi } \\
\text { Khusus, PDRB }\end{array}$ & \\
\hline
\end{tabular}




\section{PENDAHULUAN}

Otonomi daerah diberlakukan di Indonesia melalui Undang-Undang No. 23 Tahun 2014 dimana menjelaskan UU ini secara lengkap membahas mengenai pemerintahan daerah yang merupakan acuan dalam penyelenggaraan otonomi daerah di Indonesia.

Lampung merupakan salah satu provinsi di Indonesia yang telah merasakan dampak diberlakukannya kebijakan otonomi daerah. Berdasarkan data Badan Pusat Statistik (BPS) Lampung tahun 2020, setiap tahunnya angka Pendapatan Asli Derah, Dana Alokasi Umum, dan Dana Alokasi Khusus mengalami perubahan yang dinamis yaitu perubahan yang fluktuasi setiap tahunnya. Berikut adalah jumlah pendapaatan asli daerah per tahun yaitu pada tahun 2016, pendapatan asli daerah sebesar Rp 1.435.883.055,94; tahun 2017 pendapatan asli daerah sebesar Rp 1.946.515.039,88; dan tahun 2018 sebesar Rp 1.755.317.338,91; sehingga Pendapatan Asli Daerah mengalami peningkatan sebesar $26 \%$ pada tahun 2017, dan mengalami penurunan sebesar $11 \%$, pada tahun 2018. (BPS: 2020). Jumlah Dana Alokasi Umum tahun 2016 sebesar Rp 11.149.780.312,-; tahun 2017 sebesar Rp 10.976.220.521,-; dan tahun 2018 sebesar Rp 11.092.837.679,-; sehingga dana alokasi umum mengalami penurunan sebesar 1.6\% tahun 2017 dan mengalami kenaikan sebesar $1.1 \%$ tahun 2018. Penurunan tersebut menunjukkan bahwa terdapat perbaikan kinerja keuangan daerah karena tingkat ketergantungan daerah terhadap Dana Perimbangan semakin berkurang. Dengan semakin menurunnya presentase DAU kab/kota juga menunjukan kemandirian daerah tersebut yang semakin baik. Jumlah dana alokasi khusus tahun 2016 sebesar Rp 1.134.480.056,-; tahun 2017 sebesar Rp 517.986.604,-; dan tahun 2018 sebesar Rp 1.324.317.040,-; sehingga dana alokasi khusus mengalami penurunan sebesar 119\% tahun 2017 dan mengalami kenaikan sebesar $61 \%$ tahun 2018. Setiap provinsi/kabupaten/kota menerima DAK dengan besaran yang tidak sama, dan ini diatur secara mendetail dalam Peraturan Pemerintah. Besaran DAK dihitung menggunakan rumus/formulasi statistik yang kompleks. Alokasi dana DAK dari pemerintah ditentukan dengan melihat keberadaan dana lainnya di daerah yang bersangkutan, seperti DBH, dan DAU.

Berdasarkan data dana perimbangan yaitu DAU dan DAK menunjukkan bahwa saat pelaksanaan desentralisasi fiskal tahun 2016-2018, penerimaan daerah yang bersumber dari dana perimbangan mengalami perubahan yang tidak tetap (fluktuatif) dari tahun ke tahun, sehingga pertumbuhan ekonomi justru mengalami fluktuasi. Pertumbuhan ekonomi menunjukkan bagaimana aktivitas ekonomi akan menambah penghasilan masyarakat di waktu tertentu. Tolok ukur pertumbuhan ekonomi adalah produk domestik bruto (PDB) yang menunjukan nilai tambah yang 
didapatkan dari kegiatan produksi ekonomi (Susanti dkk, 2000). Penelitian-penelitian sebelumnya mengenai hubungan desentralisasi fiskal dan pertumbuhan ekonomi, sebelumnya berfokus pada 26 pelaksanaan desentralisasi dengan permasalahan ketimpangan dan kesenjangan. Seperti penelitian Mafahir, Soelistyo, Abdullah (2017) yang menyimpulkan bahwa Pendapatan asli daerah berpengaruh tidak signifikan dan bersifat negatif terhadap PDRB, dana alokasi umum berpengaruh positif dan signifikan, dana alokasi khusus berpengaruh positif dan tidak signifikan terhadap PDRB. Siti Parhah (2002) berpendapat bahwa desentralisasi fiskal tidak berpengaruh signifikan terhadap Pertumbuhan ekonomi. Hal ini sangat bertolak belakang dengan penelitian Rarung (2016) berpendapat bahwa secara bersama-sama PAD dan DAU memberikan pengaruh yang sangat signifikan terhadap perkembangan. PDRB. Berdasarkan data yang diperoleh dari Badan Pusar Statistik tahun 2020 diatas, maka dari pendapatan asli daerah yang mengalami perubahan menunjukkan bahwa penggalian dana oleh pemerintah daerah propinsi melalui sumber daya asli daerah masih belum termanfaatkan dengan maksimal.

PDRB merupakan jumlah nilai tambah yang dihasilkan oleh seluruh unit usaha dalam suatu daerah tertentu (Bank Indonesia, 2015). Pada perhitungan PDRB dapat menggunakan dua harga yaitu PDRB menurut harga berlaku dan PDRB harga konstan. PDRB harga berlaku dilihat dari nilai tambah suatu barang dan jasa yang dihitung menggunakan harga yang berlaku pada tahun tersebut. PDRB menurut harga berlaku digunakan untuk mengetahui struktur ekonomi suatu daerah. Sedangkan PDRB harga konstan dilihat dari nilai tambah suatu barang dan jasa yang dihitung dengan menggunakan harga pada tahun tertentu yang dijadikan sebagai tahun acuan atau tahun dasar. PDRB konstan digunakan untuk mengetahui kemampuan sumber daya suatu daerah dalam mendorong kemampuan ekonomi secara nyata dari tahun ke tahun (BPS, 2020).

Berdasarkan Undang-Undang Nomor 33 Tahun 2004 tentang Perimbangan Keuangan Antara Pusat dan Daerah Pasal 1 angka 18 bahwa pendapatan asli daerah, selanjutnya disebut PAD adalah pendapatan yang diperoleh daerah yang dipungut berdasarkan peraturan daerah sesuai dengan peraturan perundang-undangan. Dana alokasi umum (DAU) adalah dana yang bersumber dari pendapatan APBN yang dialokasikan dengan tujuan pemerataan kemampuan keuangan antar daerah untuk mendanai kebutuhan daerah dalam rangka pelaksanaan desentralisasi. Menurut Deddi, Iswahyudi, Maulidah (2009: 56) Dana alokasi khusus (DAK) merupakan dana yang bersumber dari pendapatan APBN yang dialokasikan pada daerah tertentu untuk membantu mendanai kegiatan khusus yang merupakan urusan daerah dan merupakan bagian dari program yang menjadi prioritas nasional. Daerah tertentu adalah daerah yang dapat memperoleh alokasi DAK berdasarkan kriteria umum, kriteria khusus dan kriteria teknis. Muhammad Rizky Azumar (2011) dalam penelitiannya 
pengaruh PAD, dana perimbangan (DAU, DAK, DBH), investasi swasta, tenaga kerja terhadap Pertumbuhan ekonomi (PDRB) di provinsi Jawa Tengah tahun 2005-2009 membuktikan bahwa ada pengaruh yang signifikan, pendapatan asli daerah (PAD), dana perimbanagan, investasi swasta, dan tenaga kerja. Namun, dana perimbangan investasi swasta pengaruhnya tidak signifikan. Selanjutnya, Wiratno Bagus Suryono (2010) meneliti Analisis Pengaruh Pendapatan Asli Daerah, Tingkat Investasi dan Tenaga Kerja terhadap PDRB Jawa Tengah tahun 1994- 2008 menemukan bahwa PAD, Tingkat Investasi, Tenaga kerja berpengaruh positif dan signifikan secara parsial maupun simultan terhadap PDRB Jawa tengah. Mafahir, Abdul (2018) meneliti pengaruh PAD,DAU, dan DAK terhadap PDRB kabupaten/kota di provinsi Nusa Tenggara Barat tahun 2012-2016 menemukan bahwa Pendapatan Asli Daerah berpengaruh tidak signifikan dan bersifat negative. Dana Alokasi Umum berpengaruh positif dan signifikan. Dana Alokasi Khusus berpengaruh positif tidak signifikan.

Penelitian ini Peneliti memiliki target yang akan dicapai, yaitu: menganalisis seberapa besar pengaruh Pendapatan Asli Daerah, Dana Alokasi Umum, dan Dana Alokasi Khusus secara parsial terhadap Produk Domestik Regional Bruto Kabupaten/ Kota di Provinsi Lampung, dan menganalisis pengaruh Pendapatan Asli Daerah, Dana Alokasi Umum, dan Dana Alokasi Khusus secara bersama-sama terhadap Produk Domestik Regional Bruto Kabupaten/Kota di Provinsi Lampung. Hasil penelitian diharapkan memiliki manfaat sebagai berikut: Bagi Penulis, dapat mengetahui faktor-faktor yang mempengaruhi tingkat Produk Domestik Regional Bruto Kabupaten/Kota di Provinsi Lampung. Bagi Pemerintah Kabupaten dan Kota di Provinsi Lampung Penelitian ini diharapkan dapat menjadi bahan pertimbangan Kabupaten dan Kota dalam pengambilan kebijakan kedepannya bagi daerahnya. Sehingga kedepannya dapat mengambil kebijakan yang lebih tepat agar daerahnya makin berkembang dan maju. Bagi masyarakat dan pihak lain Dapat digunakan sebagai acuan atau referensi dan menjadi gambaran umum faktor-faktor yang dapat mempengaruhi Produk Domestik Regional Bruto Kabupaten/ Kota di Provinsi Lampung.

\section{METODE PENELITIAN}

Penelitian ini menggunakan pendekatan kuantitatif. Penelitian ini meneliti pada populasi atau sampel tertentu, pengumpulan data menggunakan instrument penelitian, analisis data bersifat kuantitatif atau statistik, dengan tujuan untuk menguji hipotesis yang telah ditetapkan. Penelitian ini dilakukan di BPS (Badan Pusat Statistik) Provinsi Lampung. Periode yang diambil dalam penelitian ini adalah mulai tahun 2016 sampai dengan tahun 2018. Penelitian ini dilakukan mulai bulan Februari 2020 sampai Mei 2020. 


\section{Populasi dan Sampel}

Populasi yang digunakan adalah Kabupaten/Kota yang terdapat di Provinsi Lampung periode penelitian pada tahun 2016-2018. Jumlah populasi yang ada yaitu 13 kabupaten dan dua kota. Sampel yang dimbil dalam penelitian ini adalah seluruh Kabupaten/Kota yang terdapat di Provinsi Lampung yang terdiri dari 13 kabupaten dan 2 kota.

\section{Definisi Operasional}

Variabel dependen (Y) yang digunakan dalam penelitian ini adalah PDRB Kabupaten/Kota Provinsi Lampung. Sedangkan, variabel independen $(\mathrm{X})$ yang digunakan dalam penelitian ini adalah sebagai berikut:

Pendapatan asli daerah (X1), Berdasarkan Undang-Undang Nomor 33 Tahun 2004 tentang Perimbangan Keuangan Antara Pusat dan Daerah Pasal 1 angka 18 bahwa pendapatan asli daerah, selanjutnya disebut PAD adalah pendapatan yang diperoleh daerah yang dipungut berdasarkan peraturan daerah sesuai dengan peraturan perundang-undangan.Data yang digunakan dalam penelitian ini menggunakan pengukuran dengan rumus sebagai berikut:

$$
\mathrm{PAD}=\mathrm{PD}+\mathrm{RD}+\mathrm{HPKDYD}+\mathrm{LPADYS}
$$

Dana alokasi umum (X2), Menurut Deddi, Iswahyudi, Maulidah (2009) Dana alokasi umum (DAU) adalah dana yang bersumber dari pendapatan APBN yang dialokasikan dengan tujuan pemerataan kemampuan keuangan antar daerah untuk mendanai kebutuhan daerah dalam rangka pelaksanaan desentralisasi. Data yang digunakan dalam penelitian ini menggunakan pengukuran dengan rumus sebagai berikut:

$$
\text { DAU }=\text { Celah Fiskal }(\mathrm{cf})+\text { Alokasi Dasar }
$$

Dana alokasi khusus (X3). Menurut Deddi, Iswahyudi, Maulidah (2009) Dana alokasi khusus (DAK) merupakan dana yang bersumber dari pendapatan APBN yang dialokasikan pada daerah tertentu untuk membantu mendanai kegiatan khusus yang merupakan urusan daerah dan merupakan bagian dari program yang menjadi prioritas nasional. Dana alokasi khusus diukur dengan menggunakan rumus:

Penerimaan Umum $=\mathrm{PAD}+\mathrm{DAU}+(\mathrm{DBH}-\mathrm{DBHDR})$ 


\section{Teknik Pengumpulan Data}

Teknik pengumpulan data merupakan langkah yang paling strategis dalam penelitian, karena tujuan utama dari penelitian adalah mendapatkan data. Tanpa mengetahui teknik pengumpulan data, maka peneliti tidak akan mendapatkan data yang memenuhi standar data yang ditetapkan (sugiyono, 2017). Teknik pengumpulan data yang digunakan dalam penelitian ini dengan cara dokumentasi, dan observasi

\section{Teknik Analisis Data}

Teknik analisa yang digunakan penelitian ini adalah teknik analisa kuantitatif yaitu analisa yang dilakukan melalui pengukuran yang berupa angka-angka dengan metode statistik. Semua analisis data dalam penelitian ini menggunakan bantuan program SPSS 20. Metode analisis statistik yang digunakan untuk pengujian hipotesis dalam penelitian ini yaitu analisis regresi linier berganda. Analisis determinasi dalam regresi linier berganda digunakan untuk mengetahui presentase sumbangan pengaruh variabel independen secara bersama-sama terhadap variable dependen. Sebelum melakukan Uji Regresi Linier Berganda terlebih dahulu melakukan uji asumsi klasik. Uji asumsi klasik yang dilakukan adalah uji normalitas data, multikolinieritas, heteroskedastisitas, dan autokorelasi. Uji hipotesis dengan menggunakan uji t, uji f, dan Koefisien determinasi (R2).

\section{HASIL DAN PEMBAHASAN}

Penelitian ini telah melewati beberapa uji prasyarat seperti uji normalitas (tabel 1), uji Multikolinieritas (Tabel 2), dan uji Autokolerasi (Tabel 3). Hasil uji tersebut dapat diamati pada sajian berikut.

Tabel 1. One-Sample Kolmogorov-Smirnov Test

\begin{tabular}{ccl}
\hline & & $\mathbf{Y}$ \\
\hline $\mathbf{N}$ & & 45 \\
\hline Normal Parameters ${ }^{\text {a,b }}$ & Mean & 7,0340 \\
& Std. Deviation & 0,35112 \\
\hline Most Extreme Differences & Absolute & 0,127 \\
& Positive & 0,099 \\
& Negative & $-0,127$ \\
\hline Kolmogorov-Smirnov Z & 0,853 \\
\hline Asymp. Sig. (2-tailed) & 0,461 \\
\hline
\end{tabular}

Sumber: Output SPSS 20

Sehingga data tersebut dapat mendapatkan keputusan, P-Value sebesar 0,461 atau P-Value $>\alpha$ dapat disimpulkan bahwa variabel Y berdistribusi normal. 
Tabel 2. Uji Multikolinieritas

\begin{tabular}{lll}
\hline \multicolumn{1}{c}{ Variabel Independen } & Tolerrance & VIF \\
\hline Pendapatan Asli Daerah (X1) & 0,712 & 1,404 \\
Dana Alokasi Umum (X2) & 0,708 & 1,412 \\
Dana Alokasi Khusus (X3) & 0,992 & 1,008 \\
\hline
\end{tabular}

Sumber: Output SPSS 20

Tabel 2 terlihat tolerance $\mathrm{X} 1=0,712 ; \mathrm{X} 2=0,708 ; \mathrm{X} 3=0,992$. Hasil perhitungan nilai tolerance tersebut menunjukkan nilai tolerance kurang dari 0,10 ini yang berarti bahwa tidak ada korelasi antar variabel independen. Untuk nilai VIF X1 =1,404; X2 =1,412; X3 = 1,008. Hasil perhitungan tersebut menunjukkan nilai VIF $<10$ ini artinya bahwa tidak ada satu variabel independen yang memiliki nilai VIF lebih dari 10. Jadi dapat disimpulkan bahwa tidak ada multikolonieritas antar variabel independen dalam regresi.

Tabel 3. Uji Autokolerasi

\begin{tabular}{ll} 
& Runs Test \\
\hline & \multicolumn{1}{c}{ Unstandardized Residual } \\
\hline Test Value & $-693033,60607$ \\
Cases < Test Value & 22 \\
Cases >= Test Value & 23 \\
Total Cases & 45 \\
Number of Runs & 26 \\
Z &, 607 \\
Asymp. Sig. (2-tailed) &, 544 \\
Sumber: Output SPSS 20 &
\end{tabular}

Tabel 3 terlihat nilai asymp.sig (2-tailed) sebesar 0,544 lebih besar > dari 0,05 maka dapat disimpulkan bahwa tidak terdapat gejala atau masalah autokolerasi. Ketiga uji prasyarat tersebut dapat menyimpulkan bahwa penelitian ini dapat dilanjutkan ke tahap uji regresi dan uji t.

Data Regresi Linier Berganda Berikut ini merupakan hasil olah data dengan menggunakan SPSS 20 untuk mengetahui pengaruh antara variabel Produk Domestik Regional Bruto (Y1) (variabel dependen) PAD (X1), DAU (X2) dan DAK (X2) (variabel independen) di Provinsi Lampung. 
Tabel 4. Uji Regresi Linier Berganda

\begin{tabular}{|c|c|c|c|c|c|c|}
\hline \multicolumn{7}{|c|}{ Coefficients $^{\mathrm{a}}$} \\
\hline & \multirow[t]{2}{*}{ Model } & \multicolumn{2}{|c|}{ Unstandardized Coefficients } & \multirow{2}{*}{$\begin{array}{c}\begin{array}{c}\text { Standardized } \\
\text { Coefficien } \\
\text { ts }\end{array} \\
\text { Beta }\end{array}$} & \multirow{2}{*}{$\mathbf{t}$} & \multirow{2}{*}{ Sig. } \\
\hline & & $\mathbf{B}$ & Std. Error & & & \\
\hline \multirow[t]{4}{*}{1} & (Constant) & 6,211 & ,058 & & 107,430 & ,000 \\
\hline & PAD & $3,567 \mathrm{E}-010$ & ,000 & ,132 & 2,032 & ,049 \\
\hline & DAU & 1,089E-009 & ,000 & ,862 & 13,194 & , 000 \\
\hline & DAK & $-7,179 \mathrm{E}-011$ &,- 063 & $-1,142$ &, 000 & 260 \\
\hline \multicolumn{6}{|c|}{ a. Dependent Variable: PDRB } & \\
\hline
\end{tabular}

Sumber: Output SPSS 20, 2020

Hasil output regresi diatas didapat persamaan regresi (dalam jutaan) sebagai berikut:

$$
\mathrm{Y}=6,211+3,567 \mathrm{X} 1+1,089 \mathrm{X} 2-7,179 \mathrm{X} 3
$$

Artinya, apabila terjadi peningkatan Pendapatan Asli Daerah sebesar 1\% maka akan memberikan pengaruh terhadap PDRB sebesar 3,567\% dan apabila terjadi peningkatan pada Dana Alokasi Umum sebesar 1\% maka akan memberikan pengaruh terhadap PDRB sebesar 1,089\% dan apabila terjadi penurunan pada Dana Alokasi Khusus sebesar 1\% maka akan memberikan pengaruh pada PDRB sebesar -7,179\%.

\section{Uji Parsial (Uji T)}

Pengujian pengaruh Pendapatan Ali Daerah terhadap PDRB secara parsial. Pada output regresi menunjukkan bahwa angka signifikansi untuk variabel PAD sebesar 0,049. Karena nilai signifikansi lebih kecil dari 0,05 maka terdapat pengaruh secara parsial dari PAD terhadap PDRB pada Kabupaten/Kota di Provinsi Lampung.

Pengujian pengaruh Dana Alokasi Umum (DAU) terhadap PDRB secara parsial. Pada output regresi menunjukkan bahwa angka signifikansi untuk variabel DAU sebesar 0,000. Karena nilai signifikansi lebih kecil dari 0,05 maka terdapat pengaruh secara parsial dari DAU terhadap PDRB pada Kabupaten/Kota di Provinsi Lampung.

Pengujian pengaruh Dana Alokasi Khusus (DAK) terhadap PDRB secara parsial. Pada output regresi menunjukkan bahwa angka signifikansi untuk variabel DAK sebesar 0,260. Karena nilai signifikansi lebih besar dari 0,05 maka tidak terdapat pengaruh yang secara parsial dari DAK terhadap PDRB pada Kabupaten/Kota di Provinsi Lampung. 


\section{Uji Simultan (F-test)}

Hasil olah data diperoleh nilai signifikansi uji F sebesar 0,000, karena nilai signifikansi lebih kecil dari 0,05 maka hasil yang diperoleh dengan tingkat signifikansi adalah H0 ditolak dan kesimpulannya terdapat pengaruh secara simultan dari Pendapatan Asli Daerah, Dana Alokasi Umum, dan Dana Alokasi Khusus terhadap PDRB.

\section{Koefisien Determinan (R2)}

Dari nilai Adjusted R Square menunjukan nilai sebesar $0.876=87,6 \% \%$. Artinya, bahwa variabel Produk Domestik Regional Bruto (Y) 87,6\% variasinya dijelaskan oleh variasi variabel PAD (X1) DAU (X2) dan DAK (X3), sisanya 12,4\% di jelaskan oleh faktorfaktor lain di luar model.

Hasil penelitian yang telah dilakukan, bahwa Pendapatan Asli Daerah berpengaruh positif terhadap Produk Domestik Regional Bruto. Besarnya angka PAD menunjukkan kemampuan suatu daerah dalam melaksanakan desentralisasi fiskal. Jika angka PAD meningkat maka dana yang dimiliki oleh pemerintah daerah akan lebih tinggi dan tingkat kemandirian daerah akan meningkat atau ketergantungan terhadap pemerintah berkurang. Sehingga, pemerintah daerah akan berinisiatif untuk lebih menggali potensi daerah yang dimiliki dan juga meningkatkan Produk Domestik Regional Bruto. Hasil penelitian ini sama dengan penelitian yang dilakukan oleh Muhammad Rizky Azumar (2011) yang menyatakan bahwa Pendapatan Asli Daerah berpengaruh positif terhadap Produk Domestik Regional Bruto. Hal ini juga diperkuat dengan adanya penelitian dan Wiratno Bagus Suryono (2010) yang menyatakan bahwa PAD berpengaruh positif dan signifikan secara parsial terhadap PDRB.

Dana Alokasi Umum berpengaruh positif terhadap Produk Domestik Regional Bruto, artinya semakin meningkatnya Dana Alokasi Umum, maka semakin besar juga Produk Domestik Regional Bruto yang dihasilkan oleh suatu kabupaten/kota di Provinsi Lampung. Hasil penelitian ini sama dengan penelitian yang dilakukan oleh Abdul Mafahir (2018) yang menyatakan bahwa Dana Alokasi Umum berpengaruh positif terhadap PDRB. Dana Alokasi Khusus tidak berpengaruh dan bersifat negatif terhadap PDRB, artinya naik atau turunnya nilai besaran Dana Alokasi Khusus tidak akan mempengaruhi Produk Domestik Regional Bruto yang dihasilkan oleh suatu kabupaten/kota di Provinsi Lampung Dana Alokasi Khusus yang diberikan oleh pemerintah tidak berpengaruh terhadap peningkatan PDRB, ini kemungkinan disebabkan karena DAK lebih difokuskan pada kegiatan khusus pada suatu daerah seperti, pembangunan, peningkatan, pengadaan, 
serta perbaikan sarana \& prasarana yang mempunyai umur ekonomis yang panjang. Sehingga tidak berpengaruh langsung terhadap PDRB dalam jangka pendek. Hasil penelitian ini sama dengan penelitian yang dilakukan Muhammad Rizky Azumar (2011) yang menyatakan bahwa DAK tidak berpengaruh secara signifikan terhadap PDRB.

\section{KESIMPULAN}

Studi ini menyimpulkan bahwa secara simultan PAD, DAU, dan DAK berpengaruh signifikan terhadap PDRB. Dan secara Parsial menunjukkan bahwa PAD dan DAU berpengaruh positif terhadap peningkatan PDRB Kabupaten/Kota di Provinsi Lampung. Sedangkan DAK tidak berpengaruh terhadap PDRB. Keterbatasan yang dialami dalam penelitian ini adalah pengambilan data dari Badan Pusat Statistik.Disarankan bagi Pemerintah Provinsi Lampung, diharapkan mampu menggali potensi dan mengembangkan sektor-sektor ekonomi daerah untuk memaksimalkan dan mengoptimalkan Pendapatan Asli Daerah. Peningkatan Pendapatan Asli Daerah akan menguntungkan pemerintah daerah karena semakin tinggi PAD maka akan menambah dana pemerintah daerah yang kemudian akan digunakan untuk membangun sarana dan prasarana di daerah tersebut sehingga kesejahteraan masyarakat pun meningkat. Bagi peneliti selanjutnya disarankan agar penelitian dilakukan pada objek lain yang lebih luas dan mencari variabel lain yg lebih berpengaruh terhadap PDRB.

\section{DAFTAR PUSTAKA}

Abdul mafahir, alis selistiyo. 2017. Analisis pengaruh PAD,DAU dan DAK terhadap PDRB Kabupaten/kota di provinsi Nusa Tenggara Barat tahun 2012-2016. Jurnal Ilmu Ekonomi. UMM Malang . Vol 1 Jilid 1/2017 Hal. 143 - 152 .

Azzumar Muhammad Rizky. 2011. Pengaruh Pendapatan Asli Daerah, Dana Perimbangan, Investasi Swasta, Tenaga Kerja Terhadap Pertumbuhan Ekonomi Di Era Desentralisasi Fiskal Tahun 2005-2009 (Studi Kasus Kabupaten/Kota Provinsi Jawa Tengah). (Skripsi. Universitas Diponegoro Semarang.)

Badan Pusat Statistik Lampung. (2016). Lampung Dalam Angka. 2020.

Badan Pusat Statistik Lampung. (2017). Lampung Dalam Angka. 2020.

Badan Pusat Statistik Lampung. (2018). Lampung Dalam Angka. 2020

Darise, N. 2008. Akuntansi Keuangan Daerah (Akuntansi Sektor Publik). Penerbit Indeks. Jakarta

Dedi Rosadi. (2011). Analisis Ekonometrika Dan Runtun Waktu Terapan dengan R. Penerbit CV. Andi Offset. Yogyakarta

Deddi, Iswahyudi,Maulidah. 2009. Akuntansi Pemerintahan. Penerbit Salemba Empat. Jakarta. 
Mafahir,abdul. 2018. Analisis Pengaruh PAD, DAU dan DAK terhadap Kabupaten/Kota di Provinsi Nusa Tenggara Barat tahun 2012-2016. (Skripsi.UMM Malang.)

Rarung Patric. 2016 Pengaruh PAD Dan DAU Terhadap PDRB Di Kota Manado tahun 2005-2014. (Skripsi. Universitas Sam Ratulangi Manado.)

Sugiyono. 2017. Metode Penelitian Kuantitatif Kualitatif dan $R \& D$. Penerbit Alfabeta. Bandung

Suryono bagus wiratno. 2010. Analisis Pengaruh Pendapatan Asli Daerah, Tingkat Investasi dan Tenaga Kerja Terhadap PDRB Jawa Tengah tahun 1994-2008. (Skripsi. Universitas Diponegoro Semarang.)

Tambunan. 2003. Analisis Pengaruh Produk Domestik Regional Bruto (PDRB), Pendidikan dan Pengangguran Terhadap Kemiskinan Di Provinsi Banten Tahun 2009-2012.( Skripsi. Universitas Islam Syarif Hidayatullah Jakarta.)

Undang-Undang Nomor 33 Tahun 2004 tentang Perimbangan Keuangan antara Pemerintah Pusat dan Pemerintahan Daerah. 